\title{
II wojna światowa w spotkaniach młodej Polki z wojennym i powojennym pokoleniem Niemców. Orientacja na podejmowanie perspektywy Innego i praca pośrednicząca - przypadek Doroty ${ }^{1}$
}

\section{Wstęp}

II wojna światowa $\mathrm{w}$ relacjach polsko-niemieckich nieustannie stanowi temat problematyczny zarówno w dyskursie elit symbolicznych (które nazbyt często wykorzystują go nie do oczyszczającego przepracowania przeszłości, ale do taktycznych posunięć w grze o władzę), jak i w prywatnych rozmowach zwykłych obywateli obu narodów. Ów drugi - potoczny dyskurs - będzie przedmiotem mojej analizy w tym artykule. Odwołam się przy tym do mikrosytuacji rozmowy, odtwarzanych w autobiograficznym wywiadzie narracyjnym, w których różna dla wojennego i powojennego pokolenia Niemców i młodej Polki pamięć wojny staje się zagrożeniem dla ładu interakcji oraz tożsamości osób zaangażowanych. Skupię się tu na przykładzie Doroty, której nastawienie charakteryzuje orientacja na zasadę przekładalności perspektyw ${ }^{2}$ otwierająca pole do - swoją drogą niełatwego - dialogu i przepracowania przeszłości osadzonego w społecznej ramie pamięci kolektywnej ofiar i sprawców.

1 Jest to nieco zmieniony fragment artykułu zamieszczonego w Księdze jubileuszowej poświęconej prof. Zbigniewowi Bokszańskiemu Tożsamość, stereotypy, nowoczesność. Zob. K. Waniek (2012).

2 Przekładalność perspektyw definiuję za Alfredem Schützem jako podstawową regułę zdroworozsądkowego myślenia, która mówi, że „mimo wszelkich indywidualnych różnic - te same przedmioty są doświadczane przez innych ludzi zasadniczo w ten sam sposób, w jaki i my je doświadczamy, i vice versa, że zatem nasze i ich schematy interpretacji cechuje ta sama typowa struktura istotności” (Schütz 1985: 253) W codziennym działaniu jest ona realizowana dzięki: idealizacji wymienialności punktów widzenia (człowiek przyjmuje, że gdyby znalazł się na miejscu swojego interakcyjnego partnera, miałby ten sam co on ogląd rzeczywistości we wszystkich jej aspektach) oraz idealizacji zgodności systemów istotności (dla spełnienia celu, ku jakiemu ma wieść dana interakcja partnerzy wskazują sobie wzajemnie te elementy, które są dla niej istotne, pomijając różnice perspektyw wynikające z odrębnych doświadczeń biograficznych, które nie odnoszą się do danej sprawy) (Schütze 1984: 148). Złamanie lub istotne podważenie tej zasady prowadzi do „nieporozumień komunikacyjnych, jak również do kryzysu zaufania do drugiej strony sporu oraz do zerwania pragmatycznego i kooperacyjnego motywu działań” (Czyżewski 1997: 87). 


\section{Krótki portret biograficzny Doroty}

Dorota urodziła się w 1982 roku w dużym polskim mieście. Ukończyła germanistykę, dwa semestry studiów spędziła w Niemczech i z wielkim zaangażowaniem oprowadza niemieckie wycieczki po Polsce i krajach nadbałtyckich. Wywiad z Dorotą został przeprowadzony wczesną wiosną 2009 roku i trwał ponad trzy godziny. Zanim poddam analizie obszerny fragment jej opowiadania o pracy zawodowej przewodnika wycieczek, która - ze względu na wysokie kompetencje komunikacyjne narratorki - polega w głównej mierze na oprowadzaniu Niemców po Polsce, nakreślę przebieg wydarzeń w życiu Doroty oraz jej biograficzny pro$\mathrm{fil}^{3}$. Dorota wychowywała się bez ojca, w rodzinie zdominowanej przez samotne kobiety. Dbając o jej wykształcenie, jeszcze w szkole podstawowej mama wysłała ją na kurs języka niemieckiego do cieszącego się dobrą renomą liceum. Tam Dorota spotka nauczycielkę niemieckiego - pełniącą później w jej biografii rolę autorytetu - która przede wszystkim stawiała na umiejętność mówienia i znajomość kultury kraju. To spotkanie jest początkiem fascynacji Doroty językiem i kulturą Niemiec. Co więcej, zainspirowana jej przykładem narratorka, rozpoczyna pracę jako przewodnik wycieczek zaraz po skończeniu szkoły średniej. Dorota chce jednak podjąć studia o problematyce międzykulturowej, co, mimo kilku podejmowanych przez nią prób, nigdy nie dochodzi do skutku. Tym samym, głównie dzięki ingerencji mamy, Dorota rozpoczyna naukę na filologii germańskiej. Nadobowiązkowość i nieustanne dążenie do perfekcji, prowadzące do fizycznego i psychicznego wycieńczenia graniczącego z depresją, jak też trapiące ją wątpliwości co do wyboru drogi zawodowej stają się poważną przeszkodą w toku jej studiów. Ponadto już na początku studiów Dorota próbuje stworzyć dom ze swoim partnerem Marcinem ${ }^{4}$ i wyprowadza się z domu rodzinnego. Tej biograficznej decyzji towarzyszy ogromne niezadowolenie ze strony rodziny, które wiedzie do bolesnego zerwania kontaktów (Dorota ze łzami w oczach opowiada o dwóch Wigiliach spędzonych bez mamy). Związek z Marcinem okazuje się nieudany. Po niezdanym egzaminie, trapiona ponownie wątpliwościami w sens studiowania germanistyki, narratorka odbywa znaczącą w swych konsekwencjach rozmowę ze swoją tutorką, która mówi jej, że: „Germanista to nie jest ten, kto mówi po niemiecku, ale ten, kto buduje mosty”. To sformułowanie początkowo wydaje się narratorce trywialne, ale z biegiem czasu wypełnia się treścią.

\footnotetext{
${ }^{3}$ Opracowanie to jest efektem seminaryjnej pracy zespołu badawczego zaangażowanego w projekt Euroidentities: Kai Kaźmierskiej, Andrzeja Piotrowskiego, Agnieszki Adamiak-Gurdały, Marcina Gońdy i mojej. Wiele cennych sugestii zawdzięczam też Fritzowi Schütze, który jest naukowym mentorem wspomnianego projektu.

4 Dla niego narratorka rezygnuje z biograficznego planu podjęcia studiów na polsko-niemieckiej uczelni, gdzie mogłaby połączyć swoje zainteresowania problematyką międzykulturową z poszerzaniem wiedzy lingwistycznej.
} 


\section{Wyjazd na studia do Niemiec - stereotyp a własne doświadcza- nie Innego}

Wyjazd na półroczne (potem przedłużone do roku) stypendium w ramach programu Erasmus do Magdeburga jest pierwszym przełomowym biograficznym doświadczeniem, które rozbudza u Doroty poczucie misji. Narratorka odkrywa w sobie powołanie do mediacji między - często zasadniczo odmiennymi - punktami widzenia w relacjach polsko-niemieckich. W czasie pobytu w Magdeburgu następuje swoiste moratorium: narratorka odrywa się od trudnej już w tym momencie relacji ze swoim partnerem, pracy zarobkowej, którą musiała wykonywać chcąc się samodzielnie utrzymywać i obciążającego programu studiów w Polsce 5 . Dorocie towarzyszą ambiwalentne odczucia. Z jednej strony, ma wreszcie możliwość, by w pełni samodzielnie decydować o swoim życiu, ma czas dla siebie i na naukę, a z drugiej strony - opowiada o pełnych grozy spotkaniach z neonazistami. Przyjrzyjmy się bliżej opisowi zdarzenia jakie miało miejsce w czasie jej pobytu w Magdeburgu w 2008 roku w czasie typowej dla studentów Erasmusa wycieczki:

(...) ja miałam faktycznie y niezbyt fajne zdarzenie... mc kiedy jechałam pociągiem... To było// pojechaliśmy mmm... zresztą to było w miarę na początku, ponieważ pojechaliśmy// pojechaliśmy... nie wiem... chyba w listopadzie// pojechał// przyjechałam do Niemiec z początkiem października....hh chyba dokładnie drugiego czy trzeciego $\mathrm{w}$ national Tag... tak... to wtedy było to święto, czyli trzeciego października (2) mmm... iii ((chrząkniecie)) w listopadzie pojechaliśmy sobie grupą do yyy na wycieczkę do Lubeki... Już wracaliśmy w ogóle pełni wrażeń i pod koniec dnia y wsiadł taki chłopak... W ogóle mówiliśmy nota bene yyy o nazistach// W ogóle podczas tej wycieczki ja (2)// Uświadomiono mnie, gdzie ja w ogóle mieszkam... mc ponieważ była wśród nas dziewczyna z socjologii, która powiedziała... że to jest największe zagłębie neonazistów w dawnych Niemczach Wschodnich. Ja jakoś wcześniej nie byłam tego świadoma (2) I akurat byliśmy krótko po tej rozmowie, po przesiadce w ogóle, bo my musieliśmy jakoś się przesiadać jadąc z tej Lubeki. Wsiedliśmy do nowego pociągu... (????) rozmawialiśmy na inny temat i nagle właśnie wsiadł taki chłopak, w takich wojskowych butach, wygolony... mc... i na czarno cały ubrany z takim ogromnym y psem (3) emmm... i usiadł tak yyy... naprzeciwko mnie... i zaraz potem// znaczy dosyć szybko zaczął mnie zagadywać w bardzo taki niezbyt fajny sposób: „Hej mała, fajna jesteś, może byśmy tego (????) i to zrobili.” W ogóle nie, nie mc... jakoś nie, nie, nie reagowałam... yyy (3) Stwierdziłam, że nie będę się odzywała, że// że go zlekceważę, na pewno się znudzi. No więc on się zaczął irytować, że właśnie nie odpowiadam, że go lekceważę yyy... ii yyy... no jeszcze tam trochę popróbował i mc... Nie wiem, stwie// patrząc z perspektywy czasu stwierdzam, że w ogóle nie myślałam//

5 W kategoriach Fritza Schützego długoterminowy plan działania polegający na intencjonalnym postawieniu się w pozycji marginalnej (Stonequist 1961) i budowania mostów pomiędzy narodami jest próbą ucieczki od systematycznie narastających trudności, nad którymi narratorka nie jest w stanie zapanować (trajektorii cierpienia). 
a jeszcze będąc po takiej rozmowie ja do końca chyba jeszcze nie skojarzyłam, że on może być właśnie tym neonazistą/... eee... ponieważ $(($ chrząka))... cm... ponieważ pomyślałam sobie// chyba tak... ponieważ zabrakło mi czerwonych szelek i... i to była jakby ((śmiejąc się)) taki element (+), że...// No chyba to nie jest, po prostu no taki trochę... chamski chłopak, ale// ale nic więcej (2) yy i wpadłam na genialny pomysł, że... skoro on usłyszy, że ja mów// rozmawiam w innym języku, to po prostu pomyśli, że ja nie rozumiem niemieckiego, ja nie rozumiem cze// co on ode mnie chce i po prostu zostawi mnie w spokoju....hh No i to było chyba najgłupsze, co zrobiłam (('́mieje się)) ponieważ... on jeszcze coś powiedział, a później... yyy... a potem yyy usłyszałam (też) pod swoim adresem: Ty głupia zagraniczna... kurwo... ja cię zaraz.hh yyy (2) mmm (3) Ich verhaue dich... czyli ((śmiejąc się)) zaraz ci pokażę (+).. [I: mhm] yyy... yyy... y i jeszcze kilka... niezbyt fajnych tekstów... dalej nie pamiętam, ale pamiętam ten początek.hh... yyy i... puścił// znaczy tak jakoś zaczął szczuć tego psa na mnie. Na szczęście miał kaganiec, ale... taki z materiału, bardzo cienki. Ten pies był ogromny// znaczy ogromny, ponieważ jak ja siedziałam, to yyy na tym siedzeniu w pociągu, to... jego pysk... był na wysokości mojej twarzy... [mhm] no to jakiś ogromny ten pies... (...) [narratorka opowiada, że w ogóle bardzo boi się psów] więc po prostu ten pies wtedy w tym pociągu.hh z tym pyskiem obok mojej twarzy, to ja po prostu tam zeszłam ((śmieje się)). Moja koleżanka (...), która już mnie trochę znała i później powiedziała, że ona nigdy nie widziała, żebym była tak blada i podobno trzy godziny do siebie dochodziłam, żeby odzyskać jakieś kolory... [I: mhm] Ja byłam strasznie przerażona, ponieważ y... on faktycznie w którymś momencie coś zaczął mówić y y y... gdzieś w jego wypowiedzi padło to słowo naz// na// nazis// neonazis i (2) eee (3) mc i ja już w którymś momencie faktycznie się wyłączyłam. Ja// ja myślałam, że on mnie wyciągnie, pobije, nie wiem, co zrobi, zaraz tam zabije a a... mmm... mmm To nie było zbyt fajne $\backslash . . . m m m . .$. eee... to to to to... to to// Ale to by// było jedno niezbyt miłe zdarzanie, choć też.hh... mmm... gdzieś mnie uczuliło, że nie muszę się czuć tak bezpiecznie w Niemczech...

To doświadczenie nie jest jednak przez nią traktowane jako potwierdzenie stereotypu Niemca-nazisty ${ }^{6}$ i, mimo tych złych doświadczeń, dokonuje symbolicznej

${ }^{6}$ Opowiadanie o poznaniu niemieckiego studenta, który bardzo jej pomagał w czasie pobytu w Magdeburgu, a o którym mówi jak o przyjacielu, potwierdza, że taki popularny stereotyp miała: Mam takiego znajomego yyy... mmm, którego nota bene pierwszy raz zobaczyłam na zajęciach z postmodernizmu... yyy (3) natomiast tak porządnie poznaliśmy się dopiero w// w semestrze letnim... na zajęciach yyy... o Heinrichu Heinem... jakoś tak ((śmieje się)) przy odmianie polskiej to dziwnie to brzmi $(+) \ldots$ mmm i tak mocno się zaprzyjaźniliśmy i do tej pory po prostu piszemy do siebie tak długie maile... me Zresztą jak ostatnio miałam w odwiedziny, to// to u niego mieszkałam... i (2) właściwie.. to// to... jak// jesteśmy jak przyjaciele tacy bliscy mm... po prostu możemy o wszystkim sobie napisać w mailach często jakieś yyy... rozprawy filozoficzne, te maile mają to// jak ni// nieraz drukuję... stronę, to po trzy strony, cztery, al// albo dłuższe (...) I on... i gdzieś głęboko zapadł w moim sercu. Na pewno jest to człowiek, który... yyy... (4) yyy no który jest bardzo ważny dla mnie i... i nie chciałabym stracić tej przyjaźni i z którym się czuje bardzo blisko... ((śmieje się)) Chociaż pamiętam naszą pierwszą reakcję na niego (+)... ponieważ w ogóle nas yyy Niemcy dosyć nas [chodzi tu o narratorkę i jej koleżankę Malwinę, 
adopcji Niemiec jako „drugiego domu”" . Proces ten ugruntowany jest w uczeniu się, fascynacji i przeżywaniu niemieckiej kultury wyższej, co wskazuje na kulturową biwalnecję narratorki (Kłoskowska 2005).

\section{Praca przewodnika i niemieccy turyści - praca pośrednicząca}

Drugim ważnym momentem jest praca przewodnika, wyróżniająca się na tle innych podejmowanych przez narratorkę zajęć zawodowych. Wydaje się, że w budowaniu międzynarodowych więzi narratorka uporczywie stara się rekonstruować utracony dom rodzinny. Tym samym, niejako z doświadczenia własnego biograficznego cierpienia rodzi się wrażliwość Doroty na odmienność, otwartość na dialog oraz chęć i umiejętność podejmowania perspektywy Innego. Kiedy narratorka staje wobec indywidualnych historii osób (Niemców będących uczestnikami wycieczki, którą się opiekuje), które prawdopodobnie w wyniku zawieruchy wojennej straciły swój dom (ojczyznę lat dzieciństwa i młodości) oraz wobec ich naznaczonej piętnem sprawcy tożsamości (zbiorowej), zaczyna wierzyć w sens swojej misji „budowania mostów”, która staje się autentycznie przeżywanym planem działania. Moment, w którym narratorka uświadamia sobie znacznie, jakie ma dla niej praca pośrednicząca między Polską a Niemcami, jest punktem zwrotnym (turning-point) w jej biografii (Strauss 1969: 93). Analizowany poniżej fragment wywiadu pochodzi z tej części, w której badacz prosi narratora (jako teoretyka własnego życia i znawcy zagadnień społecznych, w które jest uwikłany) o podzielenie się własnymi sądami, komentarzami czy opiniami (por. Rokuszewska-Pawełek 1996: 47). Dorota zapytana o to, czy oprowadzanie niemieckich wycieczek jest trudne, odpowiada, że „nieraz tak”. Następnie stawia tezę, że Niemcy

z którą wyjechała] zasz// znaczy zaszokowali... ymmm dziwili nieraz swoim sposobem bycia, a przede wszystkim mmm... nawet sposób ubierania się... że oni tak nie przywiązują wagi, albo że... no nie przeszkadza nikomu, że ma pomarańczowy szalik do niebieskiej bluzki i zielonych spodni, wiec w ogóle nas to strasznie to dziwiło. Jednak yyy...// i tak nieraz siedziałyśmy z Malwiną i patrzyłyśmy na siebie i pamiętam pierwsze (2) me wejście Uwe, a on zimą lubi nosić taki długi ((śmieje się)) skórzany płaszcz (+) a do tego jeszcze zaczesuje włosy tak do tyłu, tak się potrafi przylizać i nosi takie okularki, no po prostu jak ((śmieje się, ciszej)) Gestapo (+).. [I: mhm] I w płaszczu miał jakąś taką... przypinkę, znaczy mc... broszkę z czyimś zdjęciem... Ja stwierdziłam z daleka, że to chyba Einstein ((śmieje się)) a Malwina mówi: „Nie, to chyba Hitler.” (+) (???????) ponieważ nie wiedziałam początkowało, jak się nazywa wcześniej// nigdy// nigdy tego nie opowiedziałam Uwe... (?????) a ponieważ nie wiedziałyśmy jak się nazywa, to on miał u nas ksywę „Gestapowiec-Hitlerowiec” ((śmieje się))\# [I: ((śmieje się))\#] ((śmieje się)) ponieważ takie skojarzenia wzbu// wzbudzał. Pamiętam, że później już, jak poznałam go (+) i on mi z kolei opowiadał, że jego babcia nie znosi, jak on nosi ten skórzany płaszcz, ponieważ... budzi w niej straszne skojarzenia... A on gdzieś// jeszcze... rzucił to zdanie mc „Nie za bardzo rozumiem, czemu?”... [I: ((śmieje się))] Gdzieś// gdzieś siebie nie widzi, nie widzi, że faktycznie może budzić takie skojarzenia. I po prostu... zimą w tym płaszczu, to (3) no, jak ((śmieje się)) wyjęty z historii (+)

7 Autorem tej koncepcji jest Andrzej Piotrowski. 
w ogóle nie są łatwymi turystami, którą dokumentuje ${ }^{8}$ przypadkami ze swego doświadczenia.

I: wydaje mi się... patrząc na... nasze... relacje polsko - niemieckie, to trudna praca chyba oprowadzać Niemców po Polsce?... Czy ... jak to jest?

$\mathrm{N}$ : yyy... Nieraz tak. Nieraz tak i... yyy... Niemcy w ogóle nie są łatwymi turystami... yyy (2) aczkolwiek uważam, że łatwiejszymi niż Polacy, mc ale nie są łatwymi. Natomiast yyy ((głęboki wdech)) oni są często sami ciekawi, wielu z nich jest (2) jakby świa// mc wielu jest Niemców, którzy są świadomi tej historii, a jest wielu, którzy...// Miałam też grupy, które nie koniecznie były świadome do końca historii... (I: mhm) N: Miałam grupę, która nie wiedziała, co to jest Westerplatte... (I: mhm) N: ((pije))... Miałam akurat taki program yyy... że mieliśmy// zaczynaliśmy w Gdańsku i ostatni dn// z przewodnikiem, ale nie było Westerplatte w programie i ostatni dzień... yyy... ((głęboki wdech)) miałam spędzić z nimi sama w tym Gdańsku, musiałam coś im zaproponować i zaproponowałam Westerplatte. Oni nie wiedzieli, co to jest. Po prostu aż nie wytrzymałam. Mimo, że to było zabronione, ja niby nie mam prawa oprowadzać po Gdańsku, no ale nie wytrzymałam i na tym Westerplatte stanęłam i opowiedziałam, co to jest za miejsce i oni... oni byli zafascynowani/, oni byli tak wdzięczni, że ja im opowiedziałam// to opowiedziałam, bo oni nie wiedzieli o tym, że// że właściwie tam się rozpoczęła II wojna światowa... mmm... yyy ... mmm (3) i... no mam różnych ludzi... (I: $\mathrm{mhm}) \mathrm{N}$ : eee... Czasem jest łatwiej, czasem nie. Na pewno w każdej grupie mam kogoś, kto, no jeśli nie sam mieszkał na tych dawnych y Prusach Wschodnich, to// to ktoś z jego rodziny, który// kto się odłącza od grupy, jedzie zobaczyć ten dom, czy to miejsce... mmm... natomiast mmm (3) Nie miałam jakichś// znaczy w tym roku miałam// w poprzednim roku ((śmieje się)) we wrześniu miałam taką grupę szkoleniową... to takie praktyki robiłam $\mathrm{mmm}$ dla takiego... biura... ii... to była zupełnie inna grupa niż// niż te grupy ssss... z tego biura, dla którego normalnie pracuję, ponieważ to była// to było głównie starsi ludzie, którzy w przeszłości... często tu mieszkali w tych Prusach Wschodnich... i oni faktycznie przyjechali z takim... podejściem, że (2) my im to zabraliśmy, to są ich dawne... i my im to zabraliśmy... mc i w ogóle, jak to możliwe j jak my mogliśmy się tak zachować ((głęboki wdech)). No i nie ukrywam, że ta grupa była ciężka. Ci ludzie byli mili... (I: mhm) N: ale yyy... ja to gdzieś... no gdzieś nie// znaczy ((długi wydech)) nie byłam niegrzeczna/... (I: mhm...) N: ale moja cierpliwość też w którymś momencie się skończyła... iii... mmm (2) miałam takie małżeństwo... yyy... chociaż to też było ciekawe w ogóle z nimi porozmawiać, ponieważ większość z nich, okazało się, to byli ludzie, którzy podczas... yyy wojny gdzieś byli w tej całej aparaturze, gdzieś w systemie. Właśnie miałam małżeństwo yyy... mm... ta kobieta urodziła się w Elblągu, jej mąż yyy... pochodził... yyy z Niemiec tych ((wzdycha))...

I: Rdzennych Niemiec?

N: Rdzennych Niemiec... podczas wojny walczył jako żołnierz na froncie. Później była jakaś kobieta, która pracowała w Niemczech w jakiejś biura administracji,

8 Narratorka wprowadza tutaj tak zwane opowiadanie dokumentujące (Belegerzählung) w wywiadzie narracyjnym, które ma na celu konkretyzację postawionej tezy (Zob. Schütze 1983). 
wydawała robotnikom przymusowym przepustki, wszystkie te dokumenty... (I: $\mathrm{mhm}) \mathrm{N}$ : i miałam kilka takich osób fff w yyy... grupie. To była chyba pierwsza grupa yyy... gdzie przede wszystkim ludzie $\mathrm{w}$ takim wieku, $\mathrm{z}$ takimi doświadczeniami byli w takiej ilości skumulowani. Tak to mi się nieraz trafił jakiś dziadek, co jak zobaczyłam, że ma około 80-ciu lat, to odruchowo już liczyłam faktycznie ten wiek ii taka myśl: a co on robił ((śmieje się)) podczas wojny? (+) bo to gdzieś się nasuwa... (I: $\mathrm{mhm}$ ) N: mc natomiast... yyy... to była taka pierwsza grupa, która też w sumie do// dosyć otwarcie o// opowiadała, a ja byłam ciekawa, bo... mmm zawsze słyszałam historię z tej drugiej strony barykady....hh o mojej babci, która pracowała// była w obozie pracy, o... mc... o... o matce koleżanki mojej mamy yyy która jeszcze żyje i też słyszałam jej historię, jak to ona była w obozie pracy... i i tego typu historie. Natomiast nigdy nie słyszałam... tak osobiście historii y ludzi, którzy byli po drugiej stronie barykady... (I: $\mathrm{mhm}$ ) N: i i byłam ciekawa. Faktycznie, siadaliśmy i rozmawialiśmy...i czasami dochodziło do ostrej polemiki... eeemmm... Natomiast wszystko jakoś tak w miarę kulturalnie, chociaż yyy... mmm... chociaż tak jak po// powiedziałam, w którymś momencie kiedyś straciłam cierpliwość, ponieważ... yyy (2) Wracając do tego małżeństwa... (I: mhm) $\mathrm{N}$ : do// do tej yyy... mmm... U... Ursula to była, ta, która się urodziła w Elblągu, musiała uciekać $\mathrm{w}$ wieku lat szesnastu pod koniec wojny i ona emm... mmm cały czas żyła tym... mc (3) tymi dawnymi latami/... jak to wtedy było. Pamiętam pojechaliśmy do Elbląga, a ona wysiadła ((śmieje się)) z autokaru i (+) rozłożyła plan miasta z czasów wojny i ja mówię: że to jest taka ulica, a ona mówi: to była Hitlerstrasse, ((śmieje się)) a tutaj to był (+) tam plac Goeringa, czy ... yyy ... i cały czas: a a tutaj, to było to, a tutaj tamto... I: ((śmieje się)) N: i... i yyy ... ja z jednej strony, to rozumiem (2) yyy bo to jest// chociażby sam fakt, jak... w innym// w zupełnie innym okresie czasu, w innych warunkach, ale mieszkałam w R [miasto na wschodzie Niemiec]... i ja gdzieś czuję się tak mocno związana z R, ale (3) ale $\mathrm{z}$ drugiej strony... nic nie można było powiedzieć// nie mogłam powiedzieć, co jest teraz, co się wydarzyło, tylko ona cały czas, a co było wtedy i i... eeee... mc no i w którymś momencie gdzieś padła... yyy... taka wypowiedź, że... Polacy się zachowali okropnie wyganiając tych Niemców ((głęboki wdech)). Ja powiedziałam: No, przepraszam, ale nie dziwcie się, że po tylu latach nie chcieliśmy mieć takich sąsiadów/. A po drugie, ja doskonale potrafię zrozumieć tych ludzi, bądźmy szczerzy, pewno sama bym nie chciała mieszkać w tych czasach obok Niemca, a po drugie... no, bądźmy konsekwentni/... sporo z was uciekło samych (2) (I: mhm...) $\mathrm{N}$ : yyy (2) Ale, no pewne rzeczy nie trafiają... yyy coś było kiedyś i yyy... mc... cały czas, że my im coś zabraliśmy, więc też powiedziałam, że na przykład, że ja nie traktuje Wilna jako polskiego miasta, czy Lwowa. To są dla mnie ziemie, które należą do Ukrainy czy do Litwy... to zn// ja nie// nie czuję, żadnych roszczeń. Chociaż ja w Wilnie będąc na ulicy, to ja się czuję jak w Polsce, bo ja słyszę język polski, albo czasami rosyjski, ale gdzieś odruchowo mój mózg po prostu rozumie ten język i w pierwszej chwili czasami nie zauważam, że to jest inny język i ja się nie czuję, że to jest Polska. Mówię: „Już dosyć straciliśmy i i i zabraliście nam sporo rzeczy, nie// nie starajcie się odbierać na nowo... mc Poza tym ten świat już miną̧." I (to chyba te słowa) ich na// naj// najbardziej ubodły, że ten świat już 
minął. Mówię: ja nie żyję w tym świecie, ja się urodziłam w tej Polsce, w takich granicach jaka jest teraz.hh... jeździłam do Mikołajek na moje wakacje, jeździłam tutaj nad morze i w okolicach Elbląga y y miałam znajomych i przyjeżdżałam na wakacje. To nie jest tamten świat/ To jest moja Polska/ (2) i ja rozumiem, ja znam historię, ja wiem, że coś takiego było... ja to akceptuję... ((bardzo poważnie)) ale teraz to jest mój kraj... i nie odbierajcie mi tego (+) (2) yyy mc... No i to było coś chyba, z czym chyba było im się najtrudniej pogodzić, bo oni gdzieś jednak// u nich// ja// ja słyszałam to, że to// oni gdzieś to traktują jako ziemie// ich ziemie, im zabrane ziemie... (I: mhm) N: To była chyba najtrudniejsza grupa ((głęboki wydech))... (I: mhm... mhm) (3) N: Ale tak, to to jest zawsze dosyć ciekawe i i wiem, że tak: no oni wiedzą swoje, zwłaszcza ta moja ostatnia grupa, że ja ich nie przekonam... eeemm (2) ale z drugiej strony... no// na pewno nie// nie// Najbardziej mnie chyba irytowało to, że opowiadając nawet tą historię z XV wieku, XVI gdzieś, że jak przyjechał król Polski, że w Elblągu w którymś momencie ta ludność bardziej chciała przynależeć do Korony/, że się buntowała/, „Nie, Elbląg był zawsze niemieckim miastem.” \#((głęboki wdech)) (I: mhm)\# N: ((śmieje się)) I i i to gdzieś w pewnym momencie spowodowało, że gdzieś yyy (2) też ((śmieje się)) też tupnęłam nogą...

I: A to było takie zatrzymanie w historii jeśli chodzi o teren tylko, czy ci ludzie tak żyli przeszłością?

N: ((bierze głęboki wdech)) Żyli chyba przeszłością... (I: mhm) N: Mam wrażenie, że oni po prostu zatrzymali się w tym czterdziestym drugim, trzecim mm roku iii (2) i gdzieś po prostu cały czas z nią// nią żyją... (I: mhm) N: yyy... bry// byłam yyy bardzo// znaczy coś, co mnie bardzo zszokowało... mmm... kiedy rozmawiałam z mężem Ursuli, z tym żołnierzem yyy i... mc... i już w ogóle pierwszego wieczora podczas kolacji miałam// tak sobie go posłuchałam iii... on mi nie wyglądał aż tak staro, ale zaczęłam mieć podejrzenia, że no co najmniej był w Hitler Jugend. $\mathrm{Z}$ niektórych jego wypowiedzi, a przede wszystkim nawet jak on opowiadał o stylu życia i swoim// o swojej gimnastyce (3) (I: mhm) N: ((śmiejąc się)) i coś już mnie tknęło, że to nie jest// że to jest (+) jakaś pozostałość jakby z tamtych lat jego. On opowiadał o tych ćwiczeniach, jakie robi i i to wszystko cały czas pod takim rygorem i później się faktycznie okazało, że// że on był tym żołnierzem Wehrmachtu... yyy ((bierze głęboki oddech))... mmm (2) i on miał różne tam// i kilka rzeczy nam powiedział a// ale on też tak próbował obronić Niemców, że// że w sumie oni to nie wiedzieli, nie wiedzieli, kim był Hitler, a on przed wojną to tyle dobrego dla nich zrobił, a w sumie wtedy to nie było tak telewizji, radia, więc oni mieli zupełnie inną wizję ((głęboki wdech)). No w sumie to to, co zawsze mówią Niemcy... yyy... Ale też kiedyś powiedział: „Ale wiesz, Dorotka, ale ja do tej pory// W ogóle całą historię zaczął, przepraszam, od słów nie „byłem nazistą”, tylko powiedział: „Ich bin Nazi” (2) (I: mhm) N: I powiedział: ,Wiesz, ja potrafię tak (2) tak z rozrzewnieniem słucham... tych... yyy (2) wypowiedzi i przemówień Hitlera, Göringa, kiedy mam możliwość yyy żeby obejrzeć w telewizji, tam tych nagrań ich posłuchać... to z jednej strony ciekawi mnie, co nas wtedy tak pociągnęło?... (I: mhm) N: bo// bo// bo cały naród coś pociągnęło... (I: mhm) N: ale z drugiej strony, ((zniżonym głosem)) to mnie znowu tak... gdzieś łapie gdzieś w sercu i gdzieś// gdzieś// (+) 
znaczy, nie, nie użył tego słowa „w sercu”, ale ((zniżonym głosem)) gdzieś dalej czuje te uczucia i tak... Ja czuję tamtego ducha $(+) \ldots$ (I: $\mathrm{mhm})$ N: No i muszę powiedzieć, że to była wypowiedź, która mnie zszokowała. (2) (I: mhm) (4) N: To była grupa, po której ja (2)// Na szczęście to była ((śmiejąc się)) ostatnia grupa (+) Już później miałam jesień i... i...// po której ja musiałam chyba trochę dojść do siebie. Znaczy musiałam to wszystko przeanalizować, przetrawić i... ii któ// i sporo mnie to też tak psychicznie... jednak kosztowało to// tego// nawet usłyszenie takiej wypowiedzi...

I: $\mathrm{mhm} . . . \mathrm{mhm}(2) \mathrm{mhm}$

N: No ((śmieje się))

Podejmując próbę pokazania, na czym polega „trudność” pracy przewodnika z niemieckimi turystami, narratorka dotyka w istocie trzech różnych obszarów niemieckiej (nie)pamięci wojny, przy czym pierwszy dotyczy powojennego, a dwa pozostałe wojennego pokolenia Niemców: (1) zacierania się lub/i usuwania z pamięci wydarzeń z okresu II wojny światowej - w tym ataku na Westerplatte 1 września 1939 roku, uznawanego przez wiele lat za jej początek; (2) przywiązanie do miejsca dzieciństwa i życie przeszłością przez osoby, które urodziły się na terenach byłych Prus Wschodnich (przypadek Ursuli i jej podróż-powrót); (3) uwiedzenie i nostalgia za Trzecią Rzeszą (przypadek męża Ursuli). Przyjrzyjmy się im w usystematyzowany sposób:

1. Dorota rozpoczyna swoje opowiadanie dokumentujące od przykładu grupy Niemców, która: „nie wiedziała, co to jest Westerplatte”. Ten brak znajomości kluczowych dla przebiegu II wojny światowej wydarzeń („biała plama”) dziwi narratorkę o tyle, że - w jej niewątpliwie idealistycznym wyobrażeniu - to kanon wiedzy historycznej każdego Polaka, który winien być podzielny przez Niemców. Przyjrzyjmy się bliżej opisywanej przez Dorotę grupie: mamy tu bowiem do czynienia z powojennym pokoleniem Niemców, dla których historia Niemiec, nawet w podręcznikach szkolnych, rozpoczyna się po roku 1949 (por. Zalewski 2009: 22). Warto w tym miejscu wspomnieć, że, jak dowodzą Baumeister i Hastings, dla podtrzymania pozytywnego wyobrażenia o sobie większość grup ma tendencję do przeinaczania pamięci zbiorowej i schlebiania sobie (Baumeister, Hastings 1997: 277)9 . Twierdzą oni, że najbardziej oczywistą i najłatwiejszą drogą do budowania pozywanego kolektywnego wizerunku jest pomijanie niewygodnych faktów, a „zdarzenia, które stawiają grupę w złym świetle, mogą zostać zignorowane albo wymazane z pamięci” (tamże: 280). Jest to jedna $z$ charakterystycznych dla normalizujących tendencji w niemieckiej historii strategia dyskursowa, polegająca na usunięciu z pola uwagi problematycznego tematu. Tym samym, podopieczni turyści narratorki rzeczywiście mogli nie wiedzieć, a ona sama - wychodząc poza zakres swoich

9 Korzystam tutaj z tłumaczenia Barbary Szackiej (por. Szacka 2003: 12). 
profesjonalnych obowiązków i ryzykując utratą licencji przewodnika ${ }^{10}$ - zdecydowała się na ujawnienie i przywrócenie ważności (celowo) zatartym w pamięci zdarzeniom, jakie miały miejsce na Westerplatte. Co ciekawe, jej akt odwagi i „wypełnienie białej plamy” o własnej przeszłości spotkało się - jak sam twierdzi - z wdzięcznością uczestniczących w tej wycieczce Niemców.

2. Opisując Niemców jako turystów, Dorota stara się unikać generalizacji, ale wyróżnia wśród nich pewien typ: tych mianowicie, którzy do Polski (na tereny byłych Prus Wschodnich) przyjeżdżają w poszukiwaniu miejsc swojego pochodzenia. Kaja Kaźmierska w swojej książce Pamięć i biografia (2008) opisującej powroty do Polski ocalonych z Holocaustu, nazywa to zjawisko „podróżą-powrotem”. Jak się wydaje, w opowiadaniu Doroty taką właśnie podróż odbywa Ursula. Bierze ona udział w wyjątkowej dla narratorki wycieczce, której wszyscy uczestnicy to wojenna generacja Niemców. Ich oskarżycielska postawa i przekonanie, że to Polacy są odpowiedzialni za odebranie im „krainy dzieciństwa czy młodości”"11, drażni narratorkę. Sposób opowiadania wyraźnie odkrywa wewnętrzny dylemat Doroty w tej sytuacji: definiując siebie w kategoriach wykonywanej profesji (praca przewodnika), narratorka nie może explicite wyrazić swoich poglądów, a nawet, do pewnego stopnia, przedstawić polskiej perspektywy. Kontrowersyjne poglądy Niemców wyczerpują jednak jej cierpliwość. Dorota przestaje działać jak profesjonalista, a zaczyna prezentować się jak młoda wrażliwa kobieta (i staje się głosem ,zwykłego Polaka"), która po pierwsze, sama nie chciałaby mieć w tamtych czasach sąsiada Niemca, po drugie: utrzymuje, że będąc w podobnej sytuacji (na ternach utraconych przez Polskę), nie żywi żadnych pretensji i nie traktuje tych miejsc jak swoich, i wreszcie po trzecie, punkty pamięci kumulujące sentymentalne obrazy z przeszłości Niemców są też dla niej miejscami nasyconymi emocjami i wspomnieniami. Ten ostatni argument zostaje podkreślony egzaltowanym stwierdzeniem: „To jest teraz moja Polska”. Każda próba narratorki wymuszenia na partnerach interakcyjnych podjęcia jej perspektywy i wypracowania empatii przynosi fiasko. Jej idealistyczne nastawienie i brak świadomości tego, że „wspólnoty pamięci nie mogą wczuwać się w sytuację ofiar innych wspólnot” (Maier za: Kaźmierska 2008: 91), a „pamięć-powtórzenie opiera się wszelkiej krytyce" (Ricoeur 2006: 106), mogą stać się przyczyną biograficznego rozczarowania. Rzecz ujmując krótko: nakład pracy pośredniczącej i emocjonalne zaangażowanie narratorki spotyka się z brakiem odzewu i zrozumienia z drugiej strony. Wydaje się zatem, że Niemcy wojennego pokolenia „ugrzęźli” w pułapce pamięci-powtórzenia, która nie sprzyja przepracowaniu

${ }^{10}$ Dorota wyjaśnia później, że nie ma uprawnień przewodnika miejskiego na terenie miasta Gdańska i gdyby została przyłapana bez licencji, groziłaby jej wysoka kara pieniężna, a nawet zawieszenie prawa wykonywania zawodu.

${ }^{11}$ Baumeister i Hastings (1997) przerzucenie winy na ofiarę uznają za kolejną taktykę, której celem jest utrzymanie pozytywnego wizerunku własnej zbiorowości przez zniekształcenie przeszłości. 
trudnej przeszłości (zob. tamże: 92-106; Kaźmierska 2008: 84-86) i kurczowo trzymają się swojej wersji wydarzeń. Tymczasem sama Dorota nieustannie prezentuje postawę „rozumiejącą” i próbuje podejmować perspektywę Niemców: jest świadoma, że do tej pory znane jej były tylko rodzinne (polskie) opowieści o wojnie i ciekawią ją relacje zwykłych ludzi z drugiej strony (Niemców). Nadto, odwołując się do własnego biograficznego doświadczenia ,udomowienia"12 Magdeburga, Dorota potrafi zrozumieć zachowanie Niemców, którzy powracają do swoich rodzinnych stron. Odnosi się to również do zachowania starszej Niemki Ursuli, która w Elblągu rozkłada mapę i identyfikuje nazwy miejsc z okresu hitleryzmu.

3. Nieuwzględnianie przez Niemców przedstawianego przez nią punktu widzenia (zarówno w odniesieniu do faktów historycznych, jak też jej własnych doświadczeń), Dorota stara się wyjaśnić ich zatrzymaniem w czasie i uwikłaniem w nazistowską przeszłość. Tłumaczy to dalej na przykładzie męża Urszuli, którego nostalgia za Trzecią Rzeszą i rzewne wspomnienia „porywających” przemówień Hitlera i Göringa wydają się narratorce szokujące. Zwróćmy jednak uwagę, że Dorota nie wiąże sympatii starszego pana do przywódców nazistowskich Niemiec oraz jego (domniemanej) nadal trwającej fascynacji Hitlerjugend $z$ niedostatkami umysłowymi lecz interpretuje je w kategoriach jego własnych racjonalnych (zdroworozsądkowych) wyborów. Zakwestionowanie negatywnej i potępieńczej oceny okresu narodowego socjalizmu - a w przypadku męża Urszuli nieukrywana fascynacja i nostalgia za uwodzącym poczuciem wspólnoty narodu niemieckiego - jest dla Doroty nie do przyjęcia. To uświadamia jej, że w przypadku wojennego pokolenia Niemców wypracowanie wspólnego poglądu dotyczącego oceny wojennej przeszłości jest wyjątkowo trudne. Na uwagę zasługuje jednak fragment, kiedy Dorota stara się odtworzyć wypowiedź swojego interakcyjnego partnera, który sugeruje, że: „gdzieś łapie gdzieś w sercu” [na wspomnienie tamtych czasów - K.W.]. Wprowadzona w tym miejscu autokorekta: ,znaczy, nie, nie użył tego słowa „W sercu", ale [zniżonym głosem] gdzieś dalej czuje te uczucia i tak... Ja czuję tamtego ducha", formalne cechy prezentacji, takie jak wahanie, powtórzenia, przerwania świadczą o tym, że narratorka monitoruje swoją wypowiedź i waży słowa. Można przyjąć, że dla wzmocnienia swojej wypowiedzi i potwierdzenia tezy, że Niemcy wojennego pokolenia nigdy nie pogodzili się z utratą symbolicznej wspólnoty „My” stworzonej w okresie Trzeciej Rzeszy, Dorota nie musiała korygować swojej wypowiedzi. Tymczasem narratorka wycofuje się ze swojego początkowego sformułowania i przenosi akcent (najprawdopodobniej zgodnie z tym, co mówił mąż Ursuli) raczej na ducha epoki. Narratorka,

12 „Udomowienie” niesie ze sobą nie tylko pozytywny emocjonalny stosunek do danego miejsca, ale też oznacza poczucie bezpieczeństwa wynikające między innymi z orientacji przestrzennej i topograficznej znajomości miejsca (por. Grathoff 1990). Sama Dorota określa to miejsce jako swój ,drugi dom”, czy „domek letni”. 
dla której - jak dowiadujemy się dalej - deklaracja starszego pana: Ich bin Nazi [Jestem nazista] (przy czym akcent jest położony na teraźniejszość) jest niewątpliwym szokiem, w sposób nieuprzedzeniowy i rzetelny relacjonuje swoje spotkanie z wojennym pokoleniem Niemców. Konkludując, mimo że Dorota napotyka na fundamentalną rozbieżność co do rozumienia przeszłości obu narodów w swoich spotkaniach z wojennym pokoleniem Niemców, nadal próbuje negocjować między odmiennymi punktami widzenia, wprowadzając w życie hasło „budowania mostów”. Narratorka pokazuje swoją determinację w wykonywaniu pracy pośredniczącej (liaison work) (Hughes 1972), której celem jest thumaczenie nie tylko między odmiennymi językami, ale też między odmiennymi kulturami ${ }^{13} \mathrm{i}$ - w tym przypadku - odmiennymi pamięciami wojny. Systematyczny brak kooperacyjnej wzajemności ze strony interakcyjnych partnerów jest bez wątpienia wyzwaniem dla narratorki. Nie brak jednak cierpliwości, najważniejszej dla pracy „dopominania” (por. Ricoeur 2006; Freud 1986).

\section{Konkluzje}

Dla wielu Polaków nawet domniemane uwikłanie w nazistowską ideologię stanowi bezdyskusyjną podstawę do wykluczenia partnera interakcyjnego ze wspólny moralnej i tym samym blokuje możliwość sytuacyjnego porozumienia, ale także ogranicza możliwość budowania areny dialogu. Takie podejście, polegające na podkreślaniu nieprzekraczalnych różnic, ma kontrproduktywne konsekwencje dla oddolnych (bottom-up) procesów budowania wspólnej przestrzeni porozumienia i wspólnego świata życia. Odmienne (wykluczające się) pamięci II wojny światowej z całą pewnością blokują możliwość integracji i budowania porozumienia nie tylko w wymiarze interakcyjnych mikrosytuacji, ale też na poziomie społecznych makroprocesów. Nastawienie Doroty jest zgoła inne - charakteryzuje je (mimo będącej jej własnym doświadczeniem konfrontacji z neonazistami) nie tylko chęć poznania i zrozumienia stanowiska Niemców wojennego pokolenia, ale też gotowość do kompromisu i potrzeba wypracowania pewnego wspólnego punktu widzenia. W rezultacie narratorka rozwija przestrzeń komunikacyjną i orientuje się na przekładalność perspektyw, gotowość do uwzględniania i rozważania odmiennego punktu widzenia może, ale nie musi wiązać się z dojściem do wspólnego punktu widzenia (Czyżewski 1997: 85). Interakcja twarzą w twarz z Niemcami wojennego pokolenia kończy się co prawda niezgodą co do

\footnotetext{
${ }^{13} \mathrm{~W}$ istocie Everett Hughes jest autorem pojęcia liaison communication, które posłużyło mu do opisania pracy dwujęzycznej sekretarki w Quebeku, która nie tylko tłumaczyła z angielskiego na francuski i odwrotnie, ale również dokonywała przekładu kultur (w tym stylów komunikacyjnych charakterystycznych dla każdej z nich). Koncepcja ta została rozszerzona przez Fritza Schützego do pojęcia liaison work, a zatem pracy niezbędnej w komunikacji międzykulturowej, która polega również (a może przede wszystkim) na thumaczeniu i wyjaśnianiu punktów widzenia partnerów interakcji (zob. Czyżewski 2005: 348).
} 
interpretacji przeszłości, ale nie prowadzi Doroty do uogólnionego, negatywnego obrazu Niemców. Narratorka cierpliwie wsłuchuje się w ich wersje przeszłości, próbuje dotrzeć do źródeł ich interpretacji oraz wyraża gotowość do podjęcia dialogu.

\section{Bibliografia}

Baumeister R. E., Hastings S., 1997, Distortions of Collective Memory: How Groups Flatter and Deceive Themselves, [w:] J. W. Pennebaker, D. Paez, B. Rimé (red.), Collective Memory of Political Events: Social Psychological Perspectives, Lawrence Erlbaum Associates, Mahwah, Nowy Jork, s. 277-293.

Czyżewski M., 1997, W stronę teorii dyskursu publicznego, [w:] M. Czyżewski, S. Kowalski, A. Piotrowski (red.), Rytualny chaos. Studium dyskursu publicznego, Aureus, Kraków, s. 42-115.

Czyżewski, 2005, Öffentliche Kommunikation und Rechtsextremismus, Wydawnictwo Uniwersytetu Łódzkiego, Łódź.

Freud Z., 1986, Żałoba i melancholia, [w:] K. Pospiszyl (red.), Zygmunt Freud: czlowiek i dzieło, Ossolineum, Wrocław.

Grathoff R., 1990, Milieu und Lebenswelt, Suhrkamp, Frankfurt.

Hughes E. C., 1972, The Linguistic Division of Labour in Industrial and Urban Societies, [w:] J. A. Fishman (red.), Advances in the Sociology of Language, t. 2, The Hague, Mounton, s. 269-309.

Kaźmierska K., 2008, Biografia i pamięć. Na przykładzie pokoleniowego doświadczenia ocalonych z Zagłady, Zakład Wydawniczy Nomos, Kraków.

Kłoskowska, 2005, Kultury narodowe u korzeni, Wydawnictwo Naukowe PWN, Warszawa.

Ricoeur P., 2006, Pamięć, historia, zapomnienie, Universitas, Kraków.

Schütz A., 1984, Potoczna i naukowa interpretacja ludzkiego działania, [w:]

E. Mokrzycki (red.), Kryzys i schizma, tom 1, Państwowy Instytut Wydawniczy, Warszawa, s. 137-192.

Schütz A., 1985, Don Kichot i problem rzeczywistości, „Literatura na Świecie”, nr 2.

Schütze F., 1983, Biographieforschung und narratives Interview, "Neue Praxis", t. 13, s. 283-293.

Schütze F., 1990, Presja i wina: doświadczenia młodego żotnierza niemieckiego $w$ czasie drugiej wojny światowej i ich implikacje biograficzne, [w:] J. Włodarek, M. Ziółkowski, (red.) Metoda biograficzna w socjologii, Państwowe Wydawnictwo Naukowe, Warszawa-Poznań, s. 325-339.

Stonequist E.V., 1961, The Marginal Man, A Study In Personality and Culture Conflict, Russell \& Russlell INC, New York.

Strauss A. L., 1969, Mirrors and Masks. The Search for Identity, Sociology Press, Mill Valley. 
Szacka B., 2000, Pamięć społeczna, [w:] Encyklopedia socjologii, t. III, Oficyna Naukowa, Warszawa.

Szacka B., 2003, Historia i pamięć zbiorowa, „Kultura i Społeczeństwo”, nr 4, s. $3-15$.

Zalewski K. M., 2009, Republika Berlińska. Ewolucja niemieckiej polityki pamięci a niemiecki patriotyzm, Punkt Widzenia, Policy Briefs, Ośrodek Studiów Wschodnich, Warszawa. 